\title{
B18 - AVALIAÇÃO DE UMA FRAÇÃO PROTEICA DE 38 A 40 KDA ISOLADA DE Acinetobacter baumannii, COMO ALVO PARA IMUNOTERAPIA
}

Lucas de Almeida Machado ${ }^{1}$, Renata Fajardo Bonin ${ }^{1}$, Anna Érika Vieira de Araujo ${ }^{1}$, José Procópio Moreno Senna ${ }^{1}$,

${ }^{1}$ Bio-Manguinhos, Fundação Oswaldo Cruz, Vice-diretoria de Desenvolvimento Tenológico, Labortatório de Tecnologia Recombinante, Programa de Biofármacos, Rio de Janeiro, Brasil

INTRODUÇÃO: Acinetobacter baumannii é um importante patógeno oportunista no mundo, com alta incidência em unidades de tratamento intensivo, acometendo principalmente pacientes imunossuprimidos. Este patógeno vem apresentando resistência aos antibióticos $\beta$-lactâmicos, incluindo os carbapenens, perfil que se mostra presente em 15 a $25 \%$ dos isolados no Brasil, o que dificulta a terapêutica, abrindo espaço para alternativas como a imunoterapia.

OBJETIVOS: Em trabalho anterior realizado por nosso grupo, foi identificada uma proteína com massa de 38 a $40 \mathrm{kDa}$ com potencial imunogênico, presente em processos infecciosos causados por este patógeno. Neste trabalho, realizamos ensaios de imunização em modelo murino com a utilização da fração proteica de 38 a $40 \mathrm{kDa}$ de A. baumannii, avaliando a proteção gerada pela imunização, os anticorpos gerados e sua capacidade de neutralizar o crescimento bacteriano in vitro.

METODOLOGIA: Para a obtenção das proteínas, foram preparadas culturas de $A$. baumannii em caldo de Luria-Bertani suplementado com ampicilina. Estas foram centrifugadas e os pellets submetidos à eletroforese desnaturante em gel de poliacrilamida. Após a eletroforese, a banda de interesse (38-40kDa) foi recortada e submetida à eletroeluição. As proteínas foram precipitadas pela adição de acetona e quantificadas pelo método de Lowry. Para os ensaios em modelo animal, foram utilizados dois grupos de camundongos balb/C. Um grupo foi imunizado com a fração protéica e hidróxido de alumínio como adjuvante (priming) e o grupo controle recebeu apenas o adjuvante; após o priming foi realizado o reforço (booster) 12 dias após a primeira imunização. O sangue dos animais foi coletado no dia anterior ao priming, 11 dias após o priming e 10 dias após o booster. A avaliação da presença de anticorpos foi feita por 
imunoensaio enzimático utilizando a fração proteica ou a bactéria íntegra como antígeno. A fim de avaliar a capacidade de neutralização in vitro, um pool de soro hiperimune murino foi incubado junto a um inóculo de A. baumannii, sendo realizada a quantificação bacteriana ao longo do tempo. Os camundongos receberam após a etapa de imunização, um inóculo de $A$. baumannii suplementado com mucina, e foi realizada uma curva de sobrevida.

RESULTADOS: Foi observada uma significativa geração de anticorpos, que foram capazes de reconhecer tanto a fração proteica isolada quanto na superfície da bactéria íntegra. Os anticorpos foram também capazes de reduzir a quantidade de bactérias no ensaio de neutralização in vitro. Os testes de proteção demonstram tendência à sobrevida no grupo imunizado, mas ainda não foram conclusivos.

CONCLUSÃO: Os resultados obtidos mostraram que a fração proteica de 38 a 40 kDa é imunogênica e capaz de gerar anticorpos neutralizantes; indicando que esta proteína é um alvo promissor para a imunoterapia. Serão testados camundongos C57/B16 como modelo, já que segundo dados recentes na literatura, esta linhagem parece se adequar melhor. 